\section{Reemergence of Oropouche Fever, Northern Brazil}

\section{Raimunda do Socorro da Silva Azevedo,* Márcio Roberto Teixeira Nunes, ${ }^{*}$ Jannifer Oliveira Chiang, * Gilberta Bensabath,* Helena Baldez Vasconcelos, * Ana Yecê das Neves Pinto, ${ }^{*}$ Lívia Carício Martins, ${ }^{*}$ Hamilton Antônio de Oliveira Monteiro,* Sueli Guerreiro Rodrigues, * and Pedro Fernando da Costa Vasconcelos*}

Oropouche fever has reemerged in Parauapebas and Porto de Moz municipalities, Pará State, Brazil. Serologic analysis (immunoglobulin M-ELISA) and virus isolation confirmed Oropouche virus (OROV) in both municipalities. Nucleotide sequencing of 2 OROV isolates from each location indicated genotypes I (Parauapebas) and II (Porto de Moz) in Brazil.

$O^{\prime}$ ropouche virus (OROV), the cause of Oropouche fever, belongs to the family Bunyaviridae, genus Orthobunyavirus, Simbu serogroup (1), and is transmitted between humans in urban areas by the biting midge Culicoides paraensis $(2,3)$. This virus was first isolated from febrile forest workers in Trinidad in 1955. The first isolation in Brazil was in 1960 from the blood of a sloth (Bradypus tridactylus) (4). The epidemic potential of OROV was recognized during an outbreak in Belém, Pará State, Brazil, in 1961, where $\approx 11,000$ persons were infected (4). Over the past 45 years, many outbreaks of Oropouche fever, $\approx 500,000$ cases, have been described in the Americas. OROV has been isolated in Trinidad, Panama, Peru, and Brazil, and in the past 40 years Oropouche fever has emerged as a public health problem in tropical areas of Central and South America (3).

Members of the genus Orthobunyavirus have a tripartite, single-stranded, negative-sense RNA genome of small (S), medium (M), and large (L) RNAs that encode nucleocapsid, glycoproteins, and RNA polymerase, respectively. Phylogenetic analysis of nucleocapsid genes of different OROV strains identified 3 distinct genotypes (I, II, and III) currently circulating in Central and South America; genotypes I and II have been detected in the Brazilian Amazon (5). Recently, an OROV isolate from a marmoset (Callithrix sp.) was characterized as a member of genotype III (6).

*Instituto Evandro Chagas, Belém, Pará, Brazil

\section{The Study}

Two outbreaks of Oropuche fever occurred during 2003 and 2004. The first occurred in April-May 2003 in 2 communities (Vila Sansão, 140 inhabitants, and Vila Paulo Fontelles, 835 inhabitants).in the municipality of Parauapebas $\left(6^{\circ} 4^{\prime} \mathrm{S}, 49^{\circ} 54^{\prime} \mathrm{W}\right)$. The second outbreak occurred in July-August 2004 in 1 community (Vila Tapara, 2,000 inhabitants) in the municipality of Porto de Moz $\left(1^{\circ} 45^{\prime} \mathrm{S}\right.$, $52^{\circ} 14^{\prime} \mathrm{W}$ ) (Figure 1).

A total of 125 and 109 serum samples were collected from residents of Parauapebas and Porto de Moz, which represented $12.8 \%$ and $5.45 \%$ of all inhabitants, respectively. Criteria for sampling were a history of acute fever several weeks before or during the survey or clinical symptoms similar to those of Oropouche fever. All serum samples were analyzed by hemagglutination inhibition (HI) test (7) and immunoglobulin M-ELISA (8) for specific $\mathrm{HI}$ and IgM antibodies to OROV. HI titers $\geq 20$ and ELISA results greater than the cut-off value (optical density $\geq 0.200$ ) were considered positive (8).Virus isolation was conducted by intracranial injection of newborn mice with a $1: 10(\mathrm{v} / \mathrm{v})$ suspension of serum samples in phosphate-buffered saline, $\mathrm{pH}$ 7.4, as described elsewhere (9). Fifty-four and 11 serum samples from Parauapebas and Porto de Moz, respectively, were used for virus isolation. Identification of isolates was performed by complement fixation test as reported (9). Two OROV strains were isolated from patients in Parauapebas, and 2 strains were isolated from patients in Porto de Moz.

To genetically characterize the viruses, 2 isolates were selected from Parauapebas (Brazil 2003a and Brazil 2003b) and 2 from Porto de Moz (Brazil 2004a and Brazil 2004b). Viral RNA was extracted from Vero cells infected with human samples, and S RNA was amplified by using a 1step reverse transcription-PCR assay as described $(5,6)$.

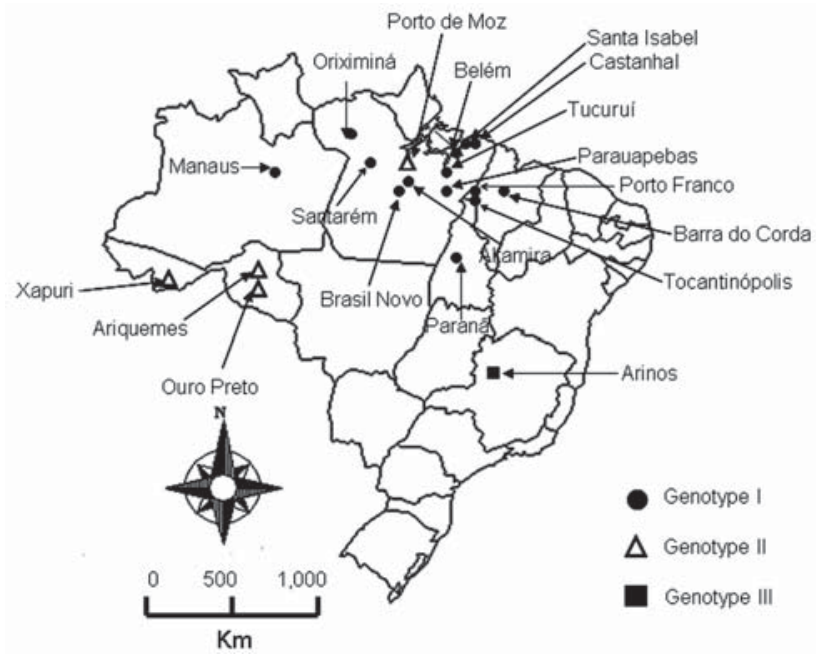

Figure 1. Map of Brazil showing locations where Oropouche fever outbreaks were identified up to 2003-2004. 
Phylogenetic trees were constructed for nucleocapsid gene nucleotide sequences by comparison with other OROV nucleocapsid gene sequences in GenBank (Table 1); neighbor-joining analysis (10) implemented in Mega version 2.1 (11) was used. Bootstrap analyses were performed on 1,000 replicates to generate confidence for groupings (12).

Of 125 serum samples from patients in Parauapebas, HI results were positive for 16 (12.7\%) from Vila Sansão, 6 (4.8\%) from Paulo Fontelles, and 4 (3.2\%) from other localities. IgM was detected in $16(12.7 \%), 8(4.8 \%)$, and $6(4.8 \%)$ serum samples from these 3 areas, respectively. Of 117 serum samples from patients in Porto de Moz, 56 (46.7\%) had $\mathrm{HI}$ antibodies and 61 (52.1\%) had IgM to OROV.
A total of $71.9 \%$ of female patients in Parauapebas and $59 \%$ in Porto de Moz had symptoms suggestive of Oropouche fever. Although all age groups were affected, persons 5-14 years of age had the highest frequency of symptoms $(30.4 \%)$ and those $<1-4$ years of age had the lowest frequency $(4.8 \%)$ (Table 2). Symptoms most frequently reported were fever $(100 \%)$, headache $(79.3 \%)$, joint pain $(68.7 \%)$, and muscle pain $(30 \%)$. Seventy percent of patients reported $\geq 1$ episode of recurrence of fever, characterized by fever, headache, and other symptoms $\approx 2-3$ weeks after onset of initial symptoms $(2,3)$.

Full-length S RNA of the 4 OROV strains contained $754 \mathrm{nt}$ and encoded 2 overlapping open reading frames, the

\begin{tabular}{|c|c|c|c|c|c|c|}
\hline Strain & Source & Sample & Year & Location & $\begin{array}{l}\text { GenBank strain } \\
\text { identification }\end{array}$ & Accession no. \\
\hline TRVL 9760 & Human & Blood & 1955 & Trinidad & Trinidad 55 & AF164531 \\
\hline BeAn 19991 & Bradypus trydactylus & Blood & 1960 & São Miguel, Brazil & Brazil 60 & AF164532 \\
\hline BeH 271815 & Human & Blood & 1975 & Santarém, Brazil & Brazil 75 & AF164533 \\
\hline BeAn 206119 & Bradypus trydactylus & Blood & 1971 & Maracanã, Brazil & Brazil 71a & AY993909 \\
\hline BeAn 208402 & Bradypus trydactylus & Blood & 1971 & Maracanã, Brazil & Brazil 71b & AY993910 \\
\hline BeAn 208819 & Bradypus trydactylus & Blood & 1971 & Maracanã, Brazil & Brazil 71c & AY993911 \\
\hline BeAn 208823 & Bradypus trydactylus & Blood & 1971 & Maracanã, Brazil & Brazil 71d & AY993912 \\
\hline BeH 390233 & Human & Blood & 1980 & Manaus, Brazil & Brazil 80c & AF164536 \\
\hline $\mathrm{BeH} 381114$ & Human & Blood & 1980 & Belém, Brazil & Brazil 80b & AF164535 \\
\hline BeH 379693 & Human & Blood & 1980 & Castanhal, Brazil & Brazil 80a & AF164534 \\
\hline $\mathrm{BeH} 472200$ & Human & Blood & 1988 & Porto Franco, Brazil & Brazil 88a & AF164537 \\
\hline $\mathrm{BeH} 472204$ & Human & Blood & 1988 & Tocantinópolis, Brazil & Brazil 88b & AF164538 \\
\hline BeAr 473358 & Culicoides paraensis & Pool & 1988 & Porto Franco, Brazil & Brazil 88c & AF164539 \\
\hline $\mathrm{BeH} 475248$ & Human & Blood & 1988 & Tucuruí, Brazil & Brazil 88d & AF164540 \\
\hline GLM 444477 & Human & Blood & 1989 & Panama & Panama 89a & AF164555 \\
\hline GLM 444911 & Human & Blood & 1989 & Panama & Panama 89b & AF164556 \\
\hline GLM 445252 & Human & Blood & 1989 & Panama & Panama 89c & AF164557 \\
\hline GLM 450093 & Human & Blood & 1989 & Panama & Panama 89d & AF164558 \\
\hline BeH 505514 & Human & Blood & 1991 & Santa Isabel, Brazil & Brazil 91a & AF164541 \\
\hline BeH 505442 & Human & Blood & 1991 & $\begin{array}{c}\text { Ouro Preto d'Oeste, } \\
\text { Brazil }\end{array}$ & Brazil 91b & AF164542 \\
\hline BeH 505663 & Human & Blood & 1991 & Ariquemes, Brazil & Brazil 91c & AF164543 \\
\hline IQT 1690 & Human & Blood & 1992 & Peru & Peru 92 & AF164549 \\
\hline MD 023 & Human & Blood & 1993 & Peru & Peru 93a & AF164550 \\
\hline DEI 209 & Human & Blood & 1993 & Peru & Peru 93b & AF164551 \\
\hline BeH 521086 & Human & Serum & 1993 & Barra do Corda, Brazil & Brazil 93 & AY704559 \\
\hline BeH 541863 & Human & Blood & 1996 & Altamira, Brazil & Brazil 96a & AF164544 \\
\hline BeH 543033 & Human & Blood & 1996 & Oriximiná, Brazil & Brazil 96b & AF164545 \\
\hline BeH 544552 & Human & Blood & 1996 & Brasil Novo, Brazil & Brazil 96c & AF164546 \\
\hline $\mathrm{BeH} 543087$ & Human & Blood & 1996 & Xapuri, Brazil & Brazil 96d & AF164547 \\
\hline BeH 543618 & Human & Blood & 1996 & Oriximiná, Brazil & Brazil 96e & AF164548 \\
\hline BeH 543733 & Human & Serum & 1996 & Oriximiná, Brazil & Brazil $96 f$ & AY704560 \\
\hline IQT 4083 & Human & Blood & 1997 & Peru & Peru 97 & AF164552 \\
\hline $01-812-98$ & Human & Blood & 1998 & Peru & Peru 98a & AF164553 \\
\hline IQT 7085 & Human & Blood & 1998 & Peru & Peru 98b & AF164554 \\
\hline BeAn 626990 & Callithrix sp. & Viscera & 2000 & Arinos, Brazil & Brazil 00 & AY117135 \\
\hline BeH 622544 & Human & Blood & 2002 & Paranã, Brazil & Brazil 02 & EF467368 \\
\hline BeH 669314 & Human & Blood & 2003 & Parauapebas, Brazil & Brazil 03a & EF467370 \\
\hline Be H 669315 & Human & Blood & 2003 & Parauapebas, Brazil & Brazil 03b & EF467369 \\
\hline BeH 682426 & Human & Blood & 2004 & Porto de Moz, Brazil & Brazil 04a & EF467371 \\
\hline $\mathrm{BeH} 682431$ & Human & Blood & 2004 & Porto de Moz, Brazil & Brazil 04b & EF467372 \\
\hline
\end{tabular}


Table 2. Distribution of serum samples positive for immunoglobulin $\mathrm{M}$ to Oropouche virus in 2 municipalities, Pará State, Brazil, 2003-2004

\begin{tabular}{|c|c|c|c|c|}
\hline \multirow{2}{*}{$\begin{array}{l}\text { Patient } \\
\text { age, y }\end{array}$} & \multicolumn{2}{|c|}{$\begin{array}{c}\text { Porto de Moz, } \\
\text { no. positive/no tested }\end{array}$} & \multicolumn{2}{|c|}{$\begin{array}{c}\text { Parauapebas, } \\
\text { no. positive/no tested }\end{array}$} \\
\hline & Male & Female & Male & Female \\
\hline$<1-4$ & $1 / 6$ & $3 / 4$ & $0 / 2$ & $1 / 9$ \\
\hline 5-14 & $11 / 21$ & $7 / 19$ & $3 / 21$ & $7 / 24$ \\
\hline $15-24$ & $2 / 7$ & $7 / 14$ & $0 / 4$ & $4 / 13$ \\
\hline $25-34$ & $4 / 7$ & $6 / 10$ & $0 / 3$ & $5 / 11$ \\
\hline $35-44$ & $4 / 5$ & $3 / 5$ & $4 / 4$ & $1 / 7$ \\
\hline $45-54$ & $2 / 3$ & $4 / 8$ & $1 / 7$ & $3 / 8$ \\
\hline$\geq 55$ & $2 / 3$ & $5 / 5$ & $1 / 6$ & $2 / 5$ \\
\hline Total & $26 / 52$ & $35 / 65$ & $9 / 47$ & $23 / 77$ \\
\hline
\end{tabular}

nucleocapsid (693 nt and 231 aa) and nonstructural protein (273 nt and $91 \mathrm{aa}$ ). Two small noncoding regions were also found at the $3^{\prime}$ and $5^{\prime}$ ends of these reading frames, spanning nt positions 1-44 and 741-754, respectively. Phylogenetic analysis of Brazil 2003 and 2004 isolates grouped strains from Parauapebas (Brazil 2003a and Brazil 2003b) into OROV genotype I and strains from Porto de $\mathrm{Moz}$ (Brazil 2004a and Brazil 2004b) into OROV genotype II (Figure 2).

\section{Conclusions}

Oropouche fever is the second most common arboviral disease (after dengue fever) in the Brazilian Amazon region. From 1960 to 1980, Oropouche fever outbreaks were detected only in Pará State, mainly in Belém and neighboring areas, where thousands of people were infected $(2,3)$. OROV was then detected in other Amazonian states including Amazonas, Amapá, Acre, Rondônia, and Tocantins; and non-Amazonian states, including Maranhão in northeastern Brazil and Tocantins in central Brazil $(3,8)$. Recently, OROV isolated from Callithrix sp.in Arinos, Minas Gerais State, southeastern Brazil was characterized as genotype III, which indicated the presence of this genotype in Brazil (6). OROV from this species has been identified only in Panama (5). From 1980 to 2005, sporadic cases or self-limited outbreaks of Oropouche fever were reported in areas of the Brazilian Amazon, which suggested silent endemic circulation of the virus (13). In 2003 and 2004, several cases of Oropouche fever were detected in Parauaebas and Porto de Moz in Pará State. Parauaebas is located in the Carajás mineral province and Porto de Moz is located in the Altamira region.

Genetic characterization of strains indicated the presence of genotype II in the eastern Amazon region. This genotype had been associated with cases of Oropouche fever in restricted western Amazonian areas (Rondônia State), as well as in Peru (5). This finding suggests movement of OROV genotype II across the Amazon region from western to eastern areas or emergence of this genotype after silent circulation for several years. Genotype I (Brazil 2003a and Brazil 2003b) found in Parauapebas was closely related to Trinidadian and Brazilian isolates obtained from 1955 through 1960 (Trinidad 55 and Brazil 60) (5). Genotype II strains isolated in Porto de Moz were genetically related to strains isolated in Peru during the 1990s (Peru 92, 93, 97, 98a, 98b) and Rondônia State in 1991 (Brazil 91a, 91b), as reported by Saeed et al. (5). These data indicate that Parauapebas and Porto de Moz OROV isolates are genetically distinct and have different ancestor viruses (Figure 2). Recognition of different OROV genotypes in the Brazilian Amazon, as well as new genetic information, is useful for understanding the epidemiology and genetic diversity of this emergent human pathogen.

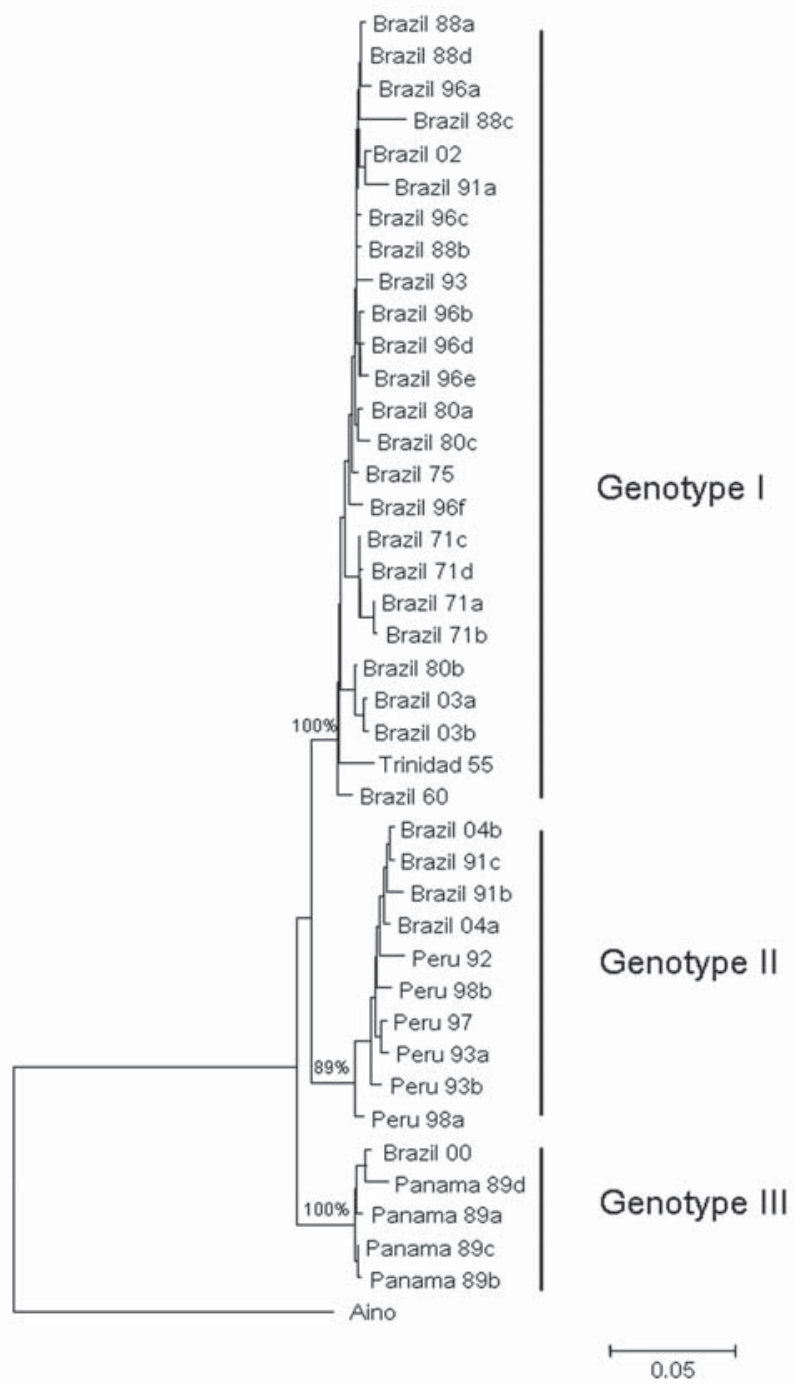

Figure 2. Comparative small (S) RNA phylogenetic tree constructed by using the neighbor-joining method for Oropouche virus strains isolated in Parauapebas and Porto de Moz, Pará State, Brazil. Bootstrap values were placed over the 3 nodes for each main group (I, II, and III). Aino virus S RNA sequence was used as an outgroup. Scale bar indicates a divergence of $5 \%$ in the nucleotide sequence. 


\section{Acknowledgments}

We thank Alan Barrett for his invaluable comments and suggestions; Vanúsia Dias Duarte, Márcia Solange Ferro de Melo Silva, Núbia Maria de Lima Costa, and Solange Medeiros da Silva for their assistance; and Basílio Silva Buna, Iveraldo Ferreira da Silva, Maxwell Furtado de Lima, Assis dos Prazeres, and Luiz Roberto Oliveira da Costa for technical support during viral isolation and serologic tests.

This study was supported by Instituto Evandro Chagas/Secretária de Vigiláncia em Saúde/Ministry of Health, Salobo Metais S/A, and CNPq (process 300460/2005-8).

Dr Azevedo is a physician in the Department of Arbovirology and Hemorrhagic Fever at the Instituto Evandro Chagas, Ministry of Health, Belém, Pará State, Brazil. Her research interests include clinical, epidemiologic, and experimental studies of arboviruses, particularly those responsible for illness in humans.

\section{References}

1. Fauquet CM, Mayo MA, Maniloff J, Desselberger U, Ball LA. Virus taxonomy: classification and nomenclature of viruses. Eighth report of the International Committee on the Taxonomy of Viruses. San Diego (CA): Academic Press; 2005.

2. Pinheiro FP, Travassos da Rosa AP, Travassos da Rosa JF, Ishak R, Freitas RB, Gomes ML, et al. Oropouche virus. I. A review of clinical, epidemiological, and ecological findings. Am J Trop Med Hyg. 1981;30:149-60.

3. Pinheiro FP, Travassos da Rosa AP, Vasconcelos PF. Oropouche fever. In: Feigin RD, editor. Textbook of pediatric infectious diseases, 5th ed. Philadelphia: Saunders; 2004. p. 2418-23.
4. Pinheiro FP, Pinheiro M, Bensabath G, Causey OR, Shope RE. Epidemia de vírus Oropouche em Belém. Revista do Servico Especial Saude Publica. 1962;12:15-23.

5. Saeed MF, Wang H, Nunes MRT, Vasconcelos PFC, Weaver SC, Shope RE, et al. Nucleotide sequences and phylogeny of the nuclecapsid gene of Oropouche virus. J Gen Virol. 2000;81:743-8.

6. Nunes MR, Martins LC, Rodrigues SG, Chiang JO, Azevedo RS, Travassos da Rosa AP, et al. Oropouche virus isolation, southeast Brazil. Emerg Infect Dis. 2005;11:1610-3.

7. Clarke DH, Casals J. Techniques for hemagglutination and hemagglutination-inhibition with arthropod-borne viruses. Am J Trop Med Hyg. 1958;7:561-73.

8. Vasconcelos PF, Travassos da Rosa JF, Guerreiro SC, Dégallier N, Travassos da Rosa ES, Travassos da Rosa AP. Primeiro registro de epidemias causadas pelo vírus Oropouche nos estados do Maranhão e Goiás, Brasil. Rev Inst Med Trop Sao Paulo. 1989;31:271-8.

9. Beaty BJ, Calisher CH, Shope RE. Arboviruses. In: Lennette DA, Schmidt NJ, editors. Diagnostic procedures for viral, rickettsial and chlamydial infections. Washington: American Public Health Association; 1995. p. 797-855.

10. Saitou N, Nei M. The neighbor-joining method: a new method for reconstruction phylogenetic trees. Mol Biol Evol. 1987;4:406-25.

11. Kumar S, Tamura K, Nei M. Molecular evolutionary genetic analysis. version 1.01. University Park (PA): The Pennsylvania State University; 2000.

12. Felsenstein J. Confidence limits on phylogenies: an approach using the bootstrap. Evolution. 1985;39:783-91.

13. Azevedo RS, Souza MR, Rodrigues SG, Nunes MR, Buna BS, Leão RNQ, Vasconcelos PF. Ocorrência endêmica de febre por Oropouche em Belém/PA no período de 2000 a 2001. Revista da Sociedade Brasileira de Medicina Tropical. 2002;35(Suppl I):386.

Address for correspondence: Pedro Fernando da Costa Vasconcelos, Seção de Arbovirologia e Febres Hemorrágicas do Instituto Evandro Chagas/SVS/MS, Ave Almirante Barroso, 492, CEP 66093-020, Belém, Pará, Brazil; email: pedrovasconcelos@iec.pa.gov.br
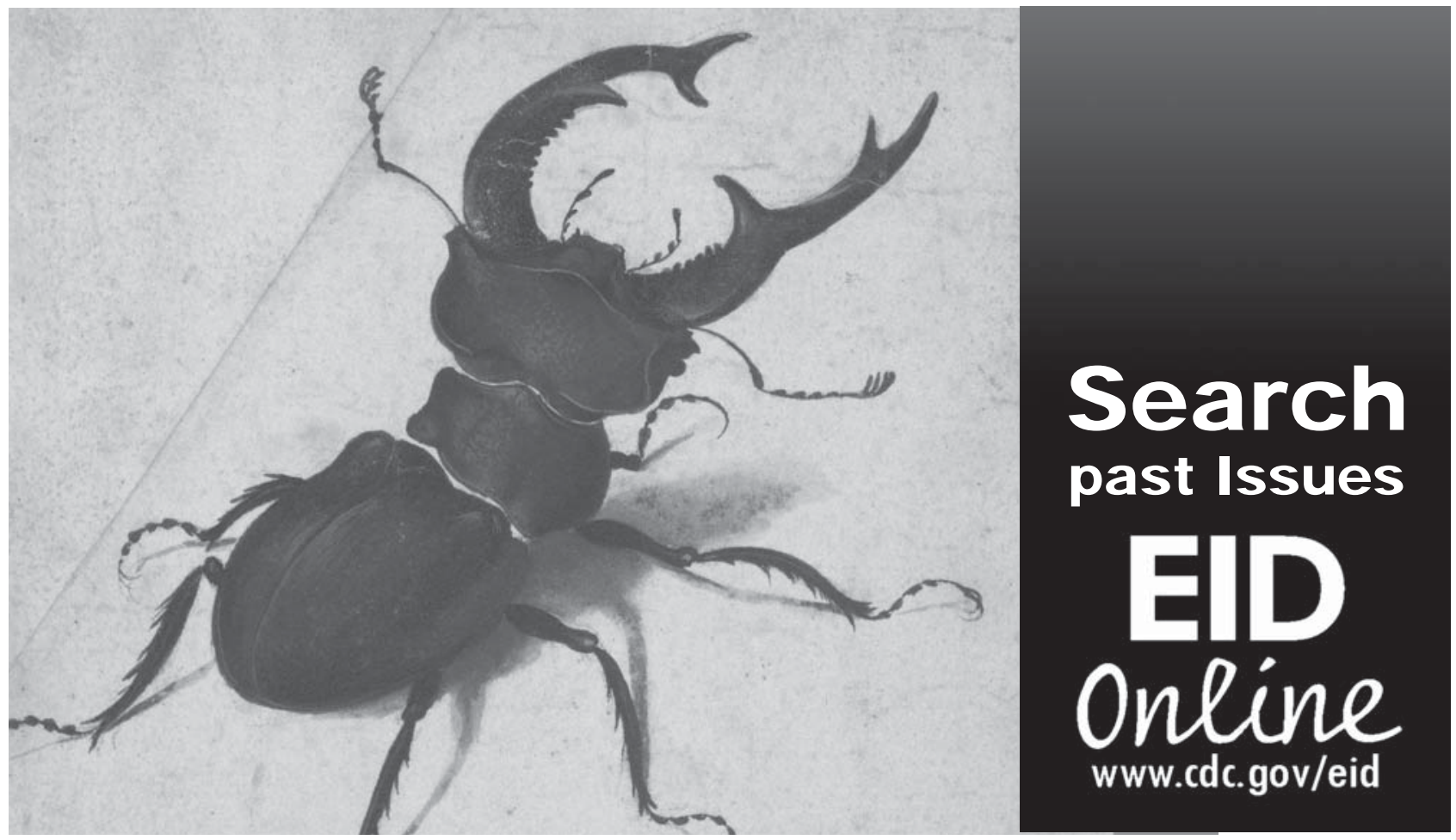